\title{
Benson Relaxation Relieve a Pain in Coronary Syndrome Patients
}

\author{
$1^{\text {st }}$ Sri Sat Titi..H \\ Nursing Departement Sekolah Tinggi \\ Ilmu Kesehatan Muhammadiyah Klaten \\ Indonesia \\ titihamrananani@stikesmukla.ac.id
}

\author{
$2^{\text {nd }}$ Retno Untar \\ Nursing Departement Sekolah Tinggi \\ Ilmu Kesehatan Muhammadiyah Klaten \\ Indonesia
}

\author{
$3^{\text {rd }}$ Daryani \\ Nursing Departement Sekolah Tinggi \\ Ilmu Kesehatan Muhammadiyah Klaten \\ Indonesia
}

\begin{abstract}
Acute coronary syndrome describes the presence of sudden ischemia in the myocardium due to loss of blood flow to the heart muscle, causing the cessation of oxygen supply to heart cells. The most common symptom is chest pain. Pain can be overcome by non-pharmacological therapy, the other is benson relaxation. The Benson Relaxation Practice can provide a relaxing and calming effect for patients so that it can change physiological responses associated with stress responses such as oxygen consumption, carbon dioxide production, heart rate, systolic blood pressure, respiratory frequency, tidal volume capacity, and vital capacity. This research to determine the effect of Benson Relaxation Technique on pain reduction in patients with Acute Coronary Syndrome. Design This research is pre-experiment with the one group pretest posttest. Respondents were obtained by accidental sampling. Data analysis using Wilcoxon. The research is Respondents were age 46-70 years, education of most high school $40 \%$, the sex of most men $70 \%$, the work of most workers and civil $40 \%$, anxiety is mostly moderate anxiety, $90 \%$ and all respondents are accompanied by family. The pain of Acute Coronary Syndrome patients before being given benson relaxation was a mean of 6 or moderate pain of $65 \%$. Pain in Acute Coronary Syndorme patients after being given benson relaxation with a mean of 3.60 or included in the category of moderate pain was $60 \%$ and mild as $40 \%$ There is an influence of benson relaxation techniques on the pain of Acute Coronary Syndrome patients with a $p$ value $=0,000$.
\end{abstract}

Keywords-Benson, Relaxation, Coronary Syndrome Patients

\section{INTRODUCTION}

Cardiovascular disease is a disease caused by impaired heart and blood vessel function. Cardiovascular disease is still the number one cause of death in the world. The World Health Organization (WHO) states that of the 17.5 million people in the world who die from cardiovascular disease, 7.3 million of them are caused by acute coronary syndrome [1] The prevalence of patients suffering from acute coronary syndrome in Indonesia is $2 \%$ and $2.1 \%$ in the Special Region of Yogyakarta[2].

Acute coronary syndrome describes the presence of sudden ischemia in the myocardial due to loss of blood flow to the heart muscle, causing the cessation of oxygen supply to heart cells[3]. Acute Coronary Syndrome (SKA) consists of unstable angina (UA), ST Segment Elevation Myocardiac Infarc (STEMI) and Non ST Elevation Myocardiac Infarc (NSTEMI) causing death and illness in almost all countries, one of them in Indonesia. States that 17.5 million $( \pm 30 \%)$ of 58 million deaths worldwide are due to heart and blood vessel disease. Heart attacks (7.6 million residents), strokes (5.7 million residents), and blood vessels (4.2 million residents) are the cause of death[1].

Symptoms of ACS include shortness of breath, chest pain, and cold sweats[4]. The most common symptom of ACS is chest pain. Chest pain is felt in the chest substernun area and normal pain is localized, the pain can spread to the neck, chin, shoulders, and upper extremities [5]

Pain can be overcome with pharmacological and nonpharmacological therapy[5]. One pharmacological therapy with narcotic opioid drugs, non-opioids / NSAIDs (Nonsteroid Anti-Inflammatory Drugs), while the nonpharmacological measures are relaxation techniques. The combination of pharmacological and non-pharmacological techniques is the most effective way to relieve pain [5]. States that the palliative method is an effective way to reduce pain. Palliative models provide advantages in terms of costs and benefits, the use of palliative methods (nonpharmacological pain management) is more economical and there are no side effects when compared to the use of pain management pharmacologically [1]

One non-pharmacological therapy is the use of the Benson Relaxation Technique (RB). Benson's Relaxation Technique is a combination of relaxation response techniques with an individual belief system (faith factor). The focus of relaxation is on certain expressions that are said repeatedly with a regular rhythm accompanied by an attitude of resignation. The words in the therapy used can be the names of God, or words that have a calming meaning for the patient himself. There are several non-pharmacological techniques that can be applied in dealing with pain, namely breathing techniques, aromatherapy, audionalgesia, 
acupuncture, transcutaneus electric nerve stimulations (TENS), cold hot compresses, touch massage and hypnosis.

One of the non-pharmacological efforts to deal with pain is relaxation techniques. Relaxation techniques are divided into 4 types, namely muscle relaxation (progressive muscle relaxation), breathing (diaphragmatic breathing), meditation (attention-focusing exercise) and behavioral relaxation [6]. The advantage of relaxation technique training compared to other techniques is that relaxation techniques are easier to do even under any conditions and do not have any side effects [7]

Benson's relaxation technique is one of the relaxation techniques that is simple, easy to implement, and does not require a lot of money, easily taught to patients. Research shows that there is a significant influence of Benson's relaxation techniques on stress levels in the elderly with a $p$ value of $0.002[7]$.

Benson's relaxation techniques affect the fulfillment of sleep needs in the elderly[8]. Another supportive study is a study about the reduction of post-surgical pain in prostate tour patients through Benson relaxation shows that there is a reduction in pain in patients who are given Benson relaxation interventions so that in this study recommending benson relaxation as consideration and use by Health care institutions as a companion to pharmacological therapy[9].

The results of research, showed a significant difference in blood pressure before and after Benson's relaxation with a value of $p=0.0001 ; \alpha=0.05[10]$. Benson's Relaxation Practices can have a relaxing and calming effect on patients so they can change the physiological responses associated with stress responses such as oxygen consumption, carbon dioxide production, heart rate, systolic blood pressure, breathing frequency, tidal volume capacity, and vital capacity. Benson's relaxation can reduce the amount of chemicals in the body such as lactic acid which can worsen pain and release endorphins[11].

\section{METHODS}

This research is quantitative type with pre experiment design with one group pretest postest design. The population in this study were all SKA patients in ICU Wonosari Gunungkidul Hospital as many as 143 people in January to December 2017. The research conducted was on Acute Coronary Syndrome patients performed pain measurements, after which Benson relaxes during 30 minutes everyday for two days. After Benson's relaxation, the respondent measured pain. The sampling technique that will be used is accidental sampling. Data analysis techniques using the Wilcoxon test.

\section{RESULTS}

The results of the study mean the age of respondents was $55 \pm 7.29$ years, shown in table I.

TABLE I. AVERAGE AGE OF RESPONDENTS

\begin{tabular}{|l|l|l|l|l|l|}
\hline & N & Min & Maks & Mean & SD \\
\hline Ages & 20 & 46 & 70 & 55 & 7,29 \\
\hline
\end{tabular}

The results of this study indicate that the average age of respondents is including the age of adulthood. The age range of the respondent, can be seen the age of the respondent is included in two categories, namely adults and the elderly.
Age has an important role in perceiving and expressing pain. Young adult patients have different responses to pain compared to the elderly. Parents need a higher intensity of pain stimulation than young age. Old adult patients assume that pain is a natural component that must be received from the aging response, so complaints are often ignored. The condition of severe pain in young adults can be felt as a mild complaint in old adults. The difference in pain intensity seen from the age factor is mostly caused by misperceptions, unstable emotions, prejudices, and defensive attitudes, so that individuals cover up the sensations of pain that are actually felt[12]

SKA is more common in adulthood, this is due to the buildup of atherosclerotic plaque that occurs for years, eventually causing a narrowing of the lumen of the heart arteries. Acute Coronary Syndrome is a chronic disease that requires a long time to cause symptoms, the disease is caused due to damage to blood vessels, and the pathophysiology can begin when an individual is young.

The results of this study are consistent with the research of Raoul and Jean (2015), where age shows the size of the time of growth and development of an individual. Age correlates positively with experience, whereas experience correlates with knowledge and understanding and outlook on an illness or event that shapes perceptions and attitudes[13].

The results of the education research respondents found that the most high school education (40\%) is shown in table II.

TABLE II. DISTRIBUTION OF EDUCATION FREQUENCY OF

\begin{tabular}{|l|l|l|l|}
\hline \multicolumn{4}{|c}{ RESPONDENTS. } \\
\hline No & Education level & Frequency & $\%$ \\
2 & Elementary & 2 & 10 \\
3 & Junior HS & 4 & 20 \\
4 & Senior HS & 8 & 40 \\
\hline & University & 6 & 30 \\
\hline
\end{tabular}

The results showed that respondents in the study had already booked secondary education. Education is a process of changing attitudes and behavior of a person in an effort to mature themselves through teaching and training efforts. This relates to coping strategies that are the consequences of each individual to assess a situation[14].

The level of education influences behavior and produces many changes, especially knowledge in the field of health. The higher a person's education the easier it is to receive information and ultimately the more knowledge he has. A person's education level in receiving information and processing it before it becomes a good or bad behavior so that it impacts on their health status [14]

The results of the gender study were predominantly male (70\%), shown in table III.

TABLE III. FREQUENCY DISTRIBUTION OF RESPONDENT

\begin{tabular}{|l|l|l|l|}
\hline \multicolumn{4}{|c|}{ GENDER. } \\
\hline 1 & Gender & Frequency & $\%$ \\
2 & Male & 14 & 70 \\
\hline & Total & 6 & 30 \\
\hline
\end{tabular}


The results showed that there were more male respondents than women. This result means that sex is one of the risk factors for ACS because coronary atherosclerosis is more susceptible to occur than men. This situation is caused by unhealthy lifestyles such as smoking and obesity, while in women it increases after menopause. Sex characteristics play a special role in responding to pain, in nursing studies can be used as a guideline in formulating nursing care so that in carrying out nursing care in male patients can use a different approach compared to female patients, especially for pain management.

This is evidenced by research from Anggriani (2015), which shows differences in the sex of men or women[15]. This shows that men are at risk of experiencing pain compared to women, this is because men have lower sensitivity than women. Whereas the female sex prefers to communicate pain to those closest to or to health workers. The results of this study are in line with the study of Wijaya (2014) which shows pain is more common in a man[16].

The results of most respondents' occupational research are civil servants and the private sector $(40 \%)$ shown in table IV.

TABLE IV. FREQUENCY DISTRIBUTION OF RESPONDENTS
WORK.
\begin{tabular}{|l|l|l|l|}
\hline No & Works & Frequency & $\%$ \\
\hline 1 & Civil Servant & 8 & 40 \\
2 & Private & 8 & 40 \\
3 & Labor & 2 & 10 \\
4 & Entrepreneur & 2 & 10 \\
\hline & Total & 20 & 100 \\
\hline
\end{tabular}

The results showed that work affects the occurrence of pain. Work that requires moderate to high activity and is carried out regularly can prevent an attack of Acute Coronary Syndrome, but after suffering an ACS even mild activity can trigger chest pain.

This study is in line with research conducted by Ramadini et al (2017), the existence of differences in work causes different gaps in routine and parts of the body will experience muscle disorders. This disorder often occurs in the back and skeletal muscles so that it will cause pain. These results are consistent with the research of Tana and Halim (2011), that occupational factors contribute to several skeletal muscle diseases and pain[17]. Furthermore WHO (2013) estimates the prevalence of skeletal muscle disorders to reach almost $60 \%$ of all occupational or occupational diseases. Thus it can be said that respondents who work will trigger pain, especially for people with SKA[1].

The effect of work on mental health is very complex. On the one hand, work is a source of personal satisfaction and achievement, interpersonal contact and financial security, and these are all prerequisites for good mental health. Lack of work or unemployment, on the other hand, can have a negative effect on our mental well-being. Those who become unemployed are twice as likely to experience an increase in depressive symptoms and be diagnosed with clinical depression as people who remain actively working. If work is not well organized and when risks at work have not been handled well, work can also have a negative effect on our mental health and well-being. Work is related to stress because if a person is faced with work demands and pressures that do not match his knowledge and skills, their ability to overcome them becomes a problem. Stress related hazards can be found in job content, workload and work speed, organization of work time, level of participation and control in decision-making.

The results of research on family assistance $100 \%$ of respondents accompanied by family, these results are shown in table $\mathrm{V}$.

TABLE V. FREQUENCY DISTRIBUTION OF RESPONDENT'S FAMILY ASSISTANCE.

\begin{tabular}{|l|l|l|l|}
\hline No & Family Assistance & Frequency & $\%$ \\
\hline 1 & Yes & 20 & 100 \\
2 & No & 0 & 0 \\
\hline & Total & 20 & 100 \\
\hline
\end{tabular}

The results of research on the decrease in respondent's pain after Benson's relaxation were 2.4. These results are shown in table VI.

TABLE VI. MEAN RESPONDENT PAIN.

\begin{tabular}{|l|l|l|l|l|l|}
\hline & $\mathrm{n}$ & Min & Mak & Mean & SD \\
\hline Pain Before & 20 & 4 & 8 & 6 & 1,29 \\
Pain After & 20 & 2 & 5 & 3,6 & 0,82 \\
\hline
\end{tabular}

The results of research on the effect of Benson's relaxation are $\mathrm{P}$ values 0,$000 ; \alpha=0.05$ shown in table VII TABLE VII. EFFECTS OF BENSON'S RELAXATION ON ACS PAIN.

\begin{tabular}{|l|l|l|l|}
\hline Groups & $\begin{array}{l}\text { Mean } \\
\text { Rank }\end{array}$ & $\mathrm{Z}$ & $\mathrm{p}$ \\
\hline $\begin{array}{l}\text { Pretest Pain (n=20) } \\
\text { Posttest Pain (n=20) }\end{array}$ & 9,50 & 3,760 & 0,000 \\
\hline
\end{tabular}

The results of the study in Tables 6 and 7 show that prior to the relaxation of Benson pain in SKA patients with a mean decrease of 2.4 with a $P$ value of 0,$000 ; \alpha=0.05$ so it can be concluded that there is an effect of Benson's relaxation techniques on pain in ACS in the Wonosari Gunungkidul General Hospital. These results are consistent with Sunaryo's (2014) study on the Effects of Benson's Relaxation on reducing chest pain in Acute myocardial infarc patients, suggesting a decrease in average pain intensity and anxiety after treatment in the intervention group.

The results of this study support research conducted by Puput Nur Fadilah, Puji Astuti, and Wesiana Heris Santy (2016) entitled The Effect of Benson Relaxation on the reduction in the scale of left chest pain in Acute Myocardial infarc patients at Dr. Moewardi Hospital Surakarta in 2014. The statistical test results showed that the $\mathrm{p}$ value in the control group was $0.004(\alpha=0.05)$, so it can be concluded that Benson's Relaxation affected the decrease in pain scale in respondents with AMI. Giving benson relaxation is effective against decreasing pain scores in postpartum caesarean mothers. This deep breathing relaxant technique can stimulate the body to produce endorphins and enfikelin[11]. These are endogenous chemical structures such as opioids, in which endorphins and enfikelin can inhibit pain implants by blocking implant transmission in the brain and spinal cord.

This study is in line with Indrawati (2018) shows that most patients do heavy physical activity, most patients experience mild-moderate chest pain. The Benson Relaxation Treatment for each patient achieves maximum results with a decrease in pain or low influence after the 
Benson relaxation treatment. Benson's Relaxation is the development of a respiratory relaxation response method involving patient confidence factors that can create an internal environment so that it can help patients achieve higher health and well-being conditions[11].

These results are consistent with Rasubala's research (2017) that before being given the Benson Relaxation technique most respondents with moderate pain[18]. Chest pain caused by physical activity because it can increase the workload of the heart. The reason is the inadequacy of oxygen supply to the heart muscle cells caused by narrowing of the arteries lumen of the heart arteries. Symptoms that arise are influenced by arterial vasospasm components and thrombus size. Thrombus is formed due to atherosclerotic plaque rupture or erosion. The process of thrombus is dynamic, the process of formation, enlargement, and lysis occur together, in this case the process of thrombus formation is more dominant than the lysis process. Ischemia and infarction in a large myocardial will result in decreased cardiac output resulting in pulmonary congestion. Dead myocardial cells will cause focal electrolyte imbalance with the worst manifestations of malignant arrhythmias, this is the main cause of death in acute coronary syndrome, namely pulmonary edema (due to congestion) or malignant arrhythmias[19]

of this study indicate a decrease in pain before being given Benson Relaxation and after Benson Relaxation. The results of the statistical test analysis using the Wilcoxon test found that the mean value in pain was 6 and the mean value in posttest pain in patients with ACS was 3.6. Benson's relaxation is a type of therapy for handling mental activities and moving the body and mind from external stimuli to prepare for a deeper relationship with the creator, which can be achieved by hypnosis methods, yoga meditation, and forms of exercises that have to do with the exploration of the mind .Benson relaxation is the development of a relaxation response method by involving patient confidence, creating a calm environment so that it can help patients achieve higher health and well-being conditions (Purwanto, 2011). Bensom Relaxation is a relaxation technique that is combined with the belief / faith held by the patient. The phrase used can be in the form of the name of God or other words that have a calming effect for patients who are read repeatedly [20] . Benson's relaxation in this case serves to reduce the intensity of pain perception by working to shift one's focus on pain by creating a comfortable atmosphere and a relaxed body, so the body will enhance the process of endogenous analgesia, this is reinforced by the presence of sentences or spells that have a calming effect or use words. words that can affect the cerebral cortex because Benson's relaxation techniques express a religious element in them. Increasingly provides a relaxing effect that ultimately increases the process of endogenous analgesia so as to reduce one's perception of pain.

Moving thoughts that are oriented to things that are logical and that is outside the self must have a constant stimulus that is one word or short phrase that is repeated in the heart in accordance with beliefs. Short words or phrases are the focus of Benson's relaxation. Focusing on short words or phrases will increase the basic strength of the relaxation response by giving the confidence factor a chance to influence the decrease in sympathetic nerve activity[20].

\section{CONCLUSION}

- The average age of $55 \pm 7.29$ years, the majority of respondents were high school education as many as 8 people $(40 \%)$, the majority of male sex were 14 people $(70 \%)$, the work of most workers and civil servants each of 8 people $(40 \%)$, the anxiety was mostly moderate, namely 18 people $(90 \%)$ and all respondents were accompanied by family.

- $\quad$ Pain of SKA patients before Benson relaxation is with a mean of 6 or moderate pain of 13 people $(65 \%)$.

- SKA patient pain after being given Benson relaxation with an average of 3.60 included in the category of moderate pain as many as 12 people $(60 \%)$ and mild pain as many as 8 people $(40 \%)$.

- There is an influence of Benson's Relaxation technique on the pain of SKA patients in ICU of Wonosari Hospital with a $\mathrm{p}$ value $=0,000$

\section{REFERENCES}

[1] WHO, Technical Pacakege For Cardiovaskuler Disease Management In Primary Health Care Switzerland. 2016.

[2] Riset Kesehatan Dasar, "Badan Penelitian dan Pengembangan Kesehatan Kementerian RI tahun 2013," 2013.

[3] R. David, E., \& Neil, Cardiology. London: Elsevier, 2015.

[4] C Susilo, "Identifikasi faktor usia, jenis kelamin dengan luas infark miokard pada penyakit jantung koroner (PJK) di ruang ICCU RSD dr.Soebandi Jember," Uniiversitas Muhammadiyah Jember, 2015.

[5] S. \& Bare, Buku Ajar Keperawatan Medikal Bedah Bruner \& Suddarth, 8th ed. Jakarta: EGC, 2012.

[6] M. Raymond, Behavior modification: Principles and procedures. Cengage Learning, 2011.

[7] K. O. Novitasari, D., \& Aryana, "Pengaruh tehnik relaksasi benson terhadap penurunan tingkat stres lansia di unit rehabilitas sosial wening wardoyo ungaran," J. keperawatan jiwa, vol. 1, pp. 186195, 2013.

[8] M. Trisnayati, "Pengaruh relaksasi Benson terhadap gangguan pola tidur lansia di unit rehabilitas sosial wening wardoyo ungaran," 2010.

[9] G. Datak, K. Yetti, R. Tutik, and S. Hariyati, "PENURUNAN NYERI PASCABEDAH PASIEN TUR PROSTAT,” 2007.

[10] C.-Y. Shih, W.-L. Lee, C.-W. Lee, C.-H. Huang, and Y.-Z. Wu, "Effect of Time Ratio of Heat to Cold on Brachial Artery Blood Velocity During Contrast Baths," Phys. Ther., vol. 92, no. 3, pp. 448-453, 2012.

[11] A. Yusliana, P. Studi, I. Keperawatan, and U. Riau, "Efektivitas relaksasi benson terhadap penurunan nyeri pada ibu postpartumsectio caesarea," J. Online Mhs., vol. 2, no. 2, 2015.

[12] P. Potter, Fundamental Of Nursing: Consep, Proses and Practice, 7th ed. Jakarta: ECG, 2015

[13] J. Raul, "Pengaruh relaksasi benson terhadap pemenuhan kebutuhan tidur pada lansia," J. kesehata, vol. 1-6, 2015.

[14] Notoatmodjo, Metode Penelitian Kesehatan. Jakarta: Rineka Cipta, 2010.

[15] Anggraini, "No Title," J. Kesehat., vol. V, pp. 109-122, 2014

[16] Wijaya IPA, "Analisis faktor-faktor yang mempengaruhi intensitas nyeri pasien pasca bedah abdomen dalam kontek asuhan keperawatan di RSUD Badung, Bali.," J. Dunia Kesehat., vol. 3, 2016.

[17] H. F. Tana L, "Determinan nyeri pinggang pada tenaga paramedis di beberapa rumah sakit di Jakarta," J indon Med Assoc, 2011.

[18] M. Rasubala, G. F, Kumat, L.T, "Pengaruh Teknik Relaksasi benson Terhadap Skala Nyeri Pada Pasien Post Operasi Di RSUP Prof DR RD Kandou dan RS TK III RW Mongisidi Manado," 2017.

[19] Tanto, "Pengaruh Pemberian Guided Imagery Terhadap Nyeri

Pada Pasien Post Operasi Frakur Di RSUD Penembahan Senopati Bantul," J. Ilm. Kesehat. Keperawatan., vol. 5, no. 1, 2014.

[20] Benson, Keimanan Yang Menyembuhkan dasar-dasar respon relaksasi. Bandung: Kaifa, 2000. 